\title{
Eight hours road transportation and ascorbic acid administration effects on haematological parameters of pigs during the harmattan season
}

\author{
A.Y. Adenkola ${ }^{* 1}$, J.O. Ayo ${ }^{2}$ A.K.B. Sackey ${ }^{3}$ and A. B. Adelaiye ${ }^{4}$ \\ ${ }^{1 *}$ Department of Physiology and Pharmacology, College of Veterinary Medicine, \\ University of Agriculture, Makurdi, Nigeria. E-mail aadenkola@yahoo.com \\ Tel +2348054977696 \\ 2Department of Physiology and Pharmacology, Faculty of Veterinary Medicine, \\ Ahmadu Bello University, Zaria, Nigeria. \\ ${ }^{3}$ Department of Surgery and Medicine, Faculty of Veterinary Medicine, Ahmadu Bello \\ University, Zaria, Nigeria \\ ${ }^{4}$ Department of Human Physiology, Faculty of Medicine, Ahmadu Bello University, \\ Zaria, Nigeria \\ ABSTRACT
}

\begin{abstract}
Experiment was conducted with the aim of investigating eight hours road transportation and ascorbic acid (AA) administration effects on haematology and serum biochemical parameters of pigs during the harmattan season. Seventeen pigs administered with AA at a dose of $250 \mathrm{mg} / \mathrm{kg}$ per os and individually served as experimental animals, and 12 others each administered orally with sterile water served as control animals. The animals were then transported for 8-h at a speed of $40-50 \mathrm{~km} / \mathrm{h}$ covering a distance of $260 \mathrm{~km}$. Blood samples were taken early in the morning a day before transportation, immediately after and a week after transportation. The leucocyte count dropped in the experimental pigs from 18,686.24 $\pm 832.51 \times 10^{3} / \mu \mathrm{l}$ before the journey to $16,790.00 \pm 782.50 \times 10^{3} / \mu \mathrm{l}$ immediately after the journey $(P>0.05)$, while the recorded values in the control pigs before $\left(17,058.33 \pm 698.25 \times 10^{3} / \mu l\right)$ transportation was significantly $(P<0.05)$ lower than the value of $19,420.67 \pm 1034.00 \times 10^{3} / \mu$ l obtained after the journey. The neutrophils: lymphocyte ratio obtained in the control animals increased from $0.36 \pm 0.04$ before transportation to $0.38 \pm 0.04$ immediately after transportation. Aspartate amino transferase and urea values were significantly different $(P<0.05)$ in the experimental and control pigs immediately after the journey. This study indicates for the first time the beneficial effect of AA administration on haematology of pigs transported by road during the harmattan season for long journey of 8-h. It is, therefore, recommended that pigs be administered with AA before transportation by road during the harmattan season in order to reduce the risk of adverse effects of transportation stress on health.
\end{abstract}

Keywords: Ascorbic acid, Harmattan season, Haematological and biochemical parameters, Pigs, Road transportation.

\section{INTRODUCTION}

The transport of live animals has important implications on both economic and welfare ground (Grandin, 1993) and a lot of animal transport is done in Nigeria, where animals are transported for the purpose of marketing and slaughter outside places where they are produced (Ayo and Oladele, 1996). The most common means of transport for all livestock species in many countries of the world is by road (Gupta et al., 2007; Buckam Sporer et al., 2008), including Nigeria (Adenkola and Ayo, 2009a; Adenkola et al., 2009a, b). Transport conditions are known to influence the physiological responses of pigs either as a result of psychological stress or physical fatique (Bradshaw et al., 1996a, b) and transportation by its nature is an unfamiliar and threatening event in the life of an animal as it involves a series of handling and confinement situations which are unavoidably stressful (Adenkola and Ayo, 2009a; Kay and Carol, 2009) causing drastic changes in the body functions as it over-exerts the body systems, adversely affecting the health and welfare of the animals thereby impairing their homeostatic mechanisms (Mstl and Palme, 2002; Adnkola and Ayo, 2009b) resulting in body dysfunctions which may be fatal.

Haematological parameters are good indicators of the physiological status of animals (Adenkola and 
Durotoye, 2004) and its changes are of value, in assessing the response of animals to various physiological stressful situations (Adenkola and Ayo, 2009a; Adenkola et al., 2009c) and disease conditions (Schalm et al. 1975). Currently in Nigeria, there is paucity of information on the haematology of pigs transported by road for long journey of 8-h, especially during the harmattan season. The harmattan season occurs in the zone between late November and early March, and it is characterized by low ambient temperature (AT) of about $10^{\circ} \mathrm{C}$ in the early morning hours and evening of the day and the season is characterized by cold-dry and dust laden wind (Igono and Aliu, 1982).This zone is characterized by intensive livestock marketing and consequently, transportation. The antioxidant property of ascorbic acid (AA) and its supplementation has been shown to be beneficial in attenuating the adverse effect of environmental stress (Kafri and Cherry, 1984; Adenkola et al., 2009a; Adenkola and Ayo, 2009b) and stressinduced tissue damage (Sen, 2001).

The aim of the present paper was to investigate the effect of 8-h road transportation and $A A$ administration during the harmattan season on haematology and serum chemistry of pigs administered ascorbic acid.

\section{MATERIALS AND METHODS}

Experimental Sites: The experiment was performed at the Livestock Pen, Faculty of Veterinary Medicine, Ahmadu Bello University, Samaru-Zaria $\left(11^{\circ} 10^{\prime} \mathrm{N}\right.$, $07^{0} 38^{\prime} \mathrm{E}$ ), located in the Northern Guinea Savannah zone of Nigeria during the harmattan season.

Experimental Animals and Management: Twenty nine local pigs, including males and non-pregnant, non-nursing females, weighing $20-48 \mathrm{~kg}$, and ages ranging from 9- 12 months were bought from different localities in Zaria environs at least two weeks before the experimental day. They were kept in a communal pen, made of concrete floor and iron walls with asbestos roofing. The pen measured 7.50 $\mathrm{m} \times 2.55 \mathrm{~m}$ with half the length of the wall to the roof without block work, which provided adequate ventilation. The pigs were not restrained inside the pen. They were kept under an intensive system of management and fed with maize offal, brewer's waste and yam peel. They were given access to water ad libitum

The pigs were pre-conditioned for two weeks before the commencement of the experiment. During the period, they were screened for haemoparasites and endoparasites by taking their blood and faecal samples for laboratory analyses. They were treated accordingly using oxytetracycline (Kepro B. $\mathrm{V}^{\circledR}$, Hollland) at the dose of $20 \mathrm{mg} / \mathrm{kg}$ by deep intramuscular route and thiabendazole $\left(\right.$ Agvet $^{\circledR}$, U.S.A.) at the dose of $25 \mathrm{mg} / \mathrm{kg}$ body weight per os.

Experimental Design: On the day of transportation, the experimental pigs $(n=17)$ were orally and individually administered with AA at $250 \mathrm{mg} / \mathrm{kg}$ (Chervyakov et al., 1977) dissolved in $20 \mathrm{ml}$ of water, while 12 pigs which served as control were given 20 $\mathrm{ml}$ of sterile water. The administrations were made immediately (15 min.) before loading the pigs into the vehicle. Food and water were withdrawn 12 hour before the journey and throughout the journey period, which lasted 8 hour. The vehicle traveled along Zaria-Jos road at a speed of $40-50 \mathrm{~km} / \mathrm{h}$ from Faculty of Veterinary Medicine, Ahmadu Bello University, Zaria $\left(11^{0} 10^{\prime} \mathrm{N}, 07^{0} 38^{\prime} \mathrm{E}\right)$, on tarred smooth and rough road covering a total distance of $260 \mathrm{~km}$ and back to the starting point. After completing the journey, the pigs were unloaded at the spot where they were original loaded. The animals were fed and watered as they had been prior to the journey.

Vehicle design, loading, and journey time: A standard Ford six wheeler bus, popularly used in Northern Nigeria in transportation of livestock was used to transport the pigs. The vehicle engine was in good condition, serviced and made ready for the journey. The floor of the vehicle was non-slippery and was covered with dry beddings before loading the animals. The inner compartment of the vehicle measured $3.22 \times 1.67 \times 1.2 \mathrm{~m}$ high. The sidewalls of the vehicle from the floor to the roof were made smooth with no protrusion of sharp edge and with a window, which provided adequate ventilation. Each window measured $0.8 \times 0.44 \mathrm{~m}$ on both sides of the vehicle, was at the height of about $1.0 \mathrm{~m}$ from the floor. A door which measured $1.4 \times 1.2 \mathrm{~m}$ was provided at the rear end of the vehicle. Other transportation procedures were carried out in accordance with the standard guidelines governing the welfare of pigs during road transportation (Warris, 1998; Lambooij, 2000). The pigs were stocked at the density of $0.8 \mathrm{~m}^{2}$ per animal. The journey commenced at 8:00 am.

Blood sample collections: Blood samples were taken early in the morning a day before transportation, immediately after and a week post-transportation. Ten millimeters of blood was taken aseptically from the anterior vena cava using a $10 \mathrm{ml}$ syringe and 18 gauge 
$x 1^{1} / 2$ inch sterile needles from each animal. Each blood sample for determination $(4 \mathrm{ml})$ of haematological parameters was immediately poured inside a sample bottle, containing an anticoagulant, disodium salt of ethylene diaminetetra-acetic acid (EDTA) at the rate of 2 $\mathrm{mg} / \mathrm{ml}$ of blood (Oyewale, 1992; Adenkola and Ayo, 2009a). After collection, the samples were transferred to Clinical Pathology Laboratory, Faculty of Veterinary Medicine, Ahmadu Bello University, Zaria, where they were analysed for packed cell volume (PCV) using microhaematocrit method, total leucocyte count using haemocytometer method as described by Schalm et al. (1975). Haemoglobin concentration and differential leucocyte count were also determined as described by Schalm et al. (1975). The remaining $(6 \mathrm{ml})$ meant for serum chemistry and serum electrolyte determination was centrifuged and the serum harvested. Alkaline phosphatase, aspartate aminotransferase, alanine amino transferase, total bilirubin, urea and total cholesterol were done as described by Cheesbrough (1991). Total protein was done using biuret method, serum albumin by Bromocresol green method as described by Cheesbrough (1991), serum globulin was determined by subtracting serum albumin from total protein value. Serum sodium and potassium ions was determined by flame emission spectrometry as described by Cheesbrough (1991), while serum bicarbonate was done using titrimetric method as described by Cheesbrough (1991) and chloride level was analylsed by the method of Schales and Schales (1941).

Statistical analysis: The data obtained were analysed using Graph Pad Prism package version 4.00 of 2003. Data were subjected to Student's $t$-test and values of $P$ $<0.05$ were considered significant.

\section{RESULTS}

Haematological Parameters Before, Immediately after, and 7 days Post-Transportation: The value of haematological parameters obtained before the journey in experimental and control pigs were not statistically different $(P>0.05)$. The recorded leucocyte value of $16,790.00 \pm 782.50 \times 10^{3} / \mu \mathrm{l}$ in experimental pigs was lower $(P<0.05)$ than the value of $19,420.67 \pm 1043.00$ $\mathrm{x} 10^{3} / \mu \mathrm{l}$ obtained in the control pigs immediately after the journey. However, the value of $16030.00 \pm 559.39$ $\mathrm{x} 10^{3} / \mu$ lobtained in the experimental pigs did not differ $(\mathrm{P}$ $>0.05$ ) from $17,058.33 \pm 698.25 \times 10^{3} / \mu \mathrm{l}$ obtained in the control pigs day 7 after the journey. The neutrophils count increased $(P<0.05)$ from 4,395.50 \pm 384.41 $\mathrm{x} 10^{3} / \mu \mathrm{l}$ before transportation to $5,278.75 \pm 387.04$ $\mathrm{x} 10^{3} / \mu \mathrm{l}$ immediately after transportation in the control pigs. In the experimental pigs the value decreased $(\mathrm{P}<$ 0.05) from $4,056.76 \pm 264.90 \times 10^{3} / \mu \mathrm{l}$ before transportation to $3,879.76 \pm 334.19 \times 10^{3} / \mu$ immediately after transportation. Although the neutrophil values obtained immediately after transportation in experimental and control pigs were significantly different $(P<0.05)$, the values thereafter dropped significantly in both experimental and control pigs $(P>0.05) 7$ days post-transportation. Immediately after the journey, the monocyte value of $118.00 \pm 41.96 \times 10^{3} / \mu \mathrm{l}$ in control pigs was significantly $(P<0.05)$ higher than $28.29 \pm 15.68$ $\times 10^{3} / \mu \mathrm{l}$ obtained in the experimental pigs (Table 1). The monocyte value $118.00 \pm 41.96 \times 10^{3} / \mu \mathrm{l}$, however, decreased $(P<0.05)$ sharply to $40.92 \pm 21.38 \times 10^{3} / \mu$ in the control pigs on day 7 post-transportation, but the decrease in experimental pigs was not significantly $(P>$ $0.05)$ different when compared to the value recorded immediately after the journey.

Serum Biochemical Parameters Before, Immediately after, and 7 days Post-Transportation: The values of the biochemical parameters obtained before transportation were not significantly $(P>0.05)$ different between the experimental and control pigs (Table 2). The $\mathrm{K}^{+}$value of $6.04 \pm 0.17 \mathrm{~mol} / \mathrm{L}$ in the control pigs before transportation dropped significantly $(P<0.05)$ to $4.92 \pm 0.16 \mathrm{~mol} / \mathrm{L}$ immediately after transportation, the value was lower $(P<0.05)$ than that recorded in the experimental pigs (Table 2). On day 7 posttransportation, however, the value rose to $8.28 \pm 2.80$ $\mathrm{mol} / \mathrm{L}$ in the experimental pigs

and did not differ significantly $(P>0.05)$ from $5.49 \pm$ $0.16 \mathrm{~mol} / \mathrm{L}$ obtained in the control pigs 7 days posttransportation. The aspartate amino transferase rose from pre-transportation value of $14.41 \pm 0.98$ I.U./L to $15.94 \pm 1.96$ I.U./L, recorded immediately after transportation in the experimental pigs, and the value was greater than the corresponding value of $13.33 \pm$ 0.98 I.U./L recorded in the control pigs, which decreased to pre-transportation mean value of $13.73 \pm$ 0.96 I.U./L. Post-transportation, on day 7 the mean value rose to $16.75 \pm 1.34 \mathrm{I} . \mathrm{U} . / \mathrm{L}$ in control animals, but was not significantly $(P>0.05)$ different from that recorded in the experimental pigs 7 days posttransportation. After the journey, alanine amino transferase value of $30.12 \pm 1.38$ I.U./L obtained in the experimental pigs was significantly higher $(P<0.05)$ than the corresponding value of $25.25 \pm 1.88$ I.U./L recorded in the control pigs (Table 2). The values of $31.67 \pm 1.27$ I.U./L and $33.67 \pm 1.69$ I.U./L obtained 7 days post-transportation in the experimental and control pigs respectively were not significantly $(P>0.05)$ different. The increase $(P<0.05)$ in the urea value obtained in the control pigs, from $4.71 \pm 0.24$ I.U./L before the journey to $7.56 \pm 2.6 \mathrm{I}$.U./L immediately after the journey, was significantly $(P<0.05)$ higher than the that of $4.94 \pm 0.19$ I.U./L obtained in the experimental pigs. The mean value increased to $5.45 \pm 0.19$ in the experimental pigs and was not significantly $(P>0.05)$ different from that obtained $(5.67 \pm 0.20 \mathrm{I} . \mathrm{U}$. /L) in the control pigs (Table 3 ). 


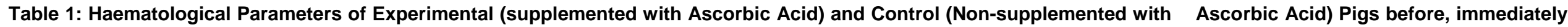
after and Day 7 after Long-Term (8-h) Road Transportation (Mean \pm SEM)

\begin{tabular}{|c|c|c|c|c|c|c|}
\hline \multirow[t]{2}{*}{ Parameters } & \multicolumn{2}{|c|}{ Before long journey } & \multicolumn{2}{|c|}{ ImmediatelyAfter long journey } & \multicolumn{2}{|c|}{ Day 7 after long journey } \\
\hline & $\begin{array}{l}\text { Experimental } \\
\quad(\mathrm{n}=17)\end{array}$ & $\begin{array}{l}\text { Control } \\
(\mathrm{n}=12)\end{array}$ & $\begin{array}{l}\text { Experimental } \\
\quad(\mathrm{n}=17)\end{array}$ & $\begin{array}{l}\text { Control } \\
(n=12)\end{array}$ & $\begin{array}{l}\text { Experimental } \\
(\mathrm{n}=17)\end{array}$ & $\begin{array}{l}\text { Control } \\
(n=12)\end{array}$ \\
\hline Packed Cell Volume (\%) & $36.35 \pm 1.04^{\mathrm{NS}}$ & $33.92 \pm 0.92^{\mathrm{NS}}$ & $32.81 \pm 1.13^{\mathrm{NS}}$ & $30.83 \pm 1.38^{\mathrm{NS}}$ & $35.59 \pm 1.17^{\mathrm{NS}}$ & $34.83 \pm 1.30^{\mathrm{NS}}$ \\
\hline Haemoglobin Concentration (gm/\%) & $12.08 \pm 0.34^{\mathrm{NS}}$ & $11.35 \pm 0.35^{\mathrm{NS}}$ & $10.91 \pm 0.38^{\mathrm{NS}}$ & $10.26 \pm 0.46^{\mathrm{NS}}$ & $11.82 \pm 0.39^{N S}$ & $11.94 \pm 0.55^{\mathrm{NS}}$ \\
\hline Total leucocyte Count $\left(\times 10^{3} / \mu \mathrm{l}\right)$ & $18,688.24 \pm 832.51^{\mathrm{NS}}$ & $17,058.33 \pm 698.25^{\mathrm{NS}}$ & $16,790.00 \pm 782.50^{\mathrm{a}}$ & $19,420.67 \pm 1034.00^{b}$ & $16,030.00 \pm 559.39^{N S}$ & $17,058.33 \pm 698.25^{\mathrm{NS}}$ \\
\hline Neutrophils $\left(\times 10^{3} / \mu \mathrm{l}\right)$ & $4,056.76 \pm 264.90^{N S}$ & $4,395.50 \pm 348.41^{N S}$ & $3,879.76 \pm 334.19^{a}$ & $5,278.75 \pm 387.04^{b}$ & $4,068.76 \pm 225.31^{N S}$ & $4,395.50 \pm 348.41^{\mathrm{NS}}$ \\
\hline Eosinophils $\left(\times 10^{3} / \mu \mathrm{l}\right)$ & $80.82 \pm 30.10^{\mathrm{NS}}$ & $40.08 \pm 21.03^{\mathrm{NS}}$ & $70.70 \pm 29.44^{\mathrm{NS}}$ & $73.08 \pm 31.40^{\mathrm{NS}}$ & $57.17 \pm 26.51^{\mathrm{NS}}$ & $74.55 .34 \pm 34.74$ \\
\hline Monocyte $\left(\times 10^{3} / \mu \mathrm{l}\right)$ & $97.41 \pm 29.08^{\mathrm{NS}}$ & $84.16 \pm 30.99^{\mathrm{NS}}$ & $28.29 \pm 15.68^{a}$ & $118.00 \pm 41.96^{\mathrm{b}}$ & $34.59 \pm 15.76^{\mathrm{NS}}$ & $40.92 \pm 21.38^{\mathrm{NS}}$ \\
\hline Neutrophil : Lymphocyte & $0.28 \pm 0.02^{a}$ & $0.36 \pm 0.04^{a}$ & $0.31 \pm 0.03^{b}$ & $0.38 \pm 0.03^{b}$ & $0.34 \pm 0.01^{\mathrm{NS}}$ & $0.36 \pm 0.02^{\mathrm{NS}}$ \\
\hline $\begin{array}{l}\text { Mean Corpuscular Haemoglobin } \\
\text { Concentration }\end{array}$ & $33.34 \pm 0.11^{\mathrm{NS}}$ & $33.44 \pm 0.21^{\mathrm{NS}}$ & $33.24 \pm 0.02^{\mathrm{NS}}$ & $33.27 \pm 0.02^{\mathrm{NS}}$ & $33.22 \pm 0.02^{\mathrm{NS}}$ & $33.47 \pm 0.02^{\mathrm{NS}}$ \\
\hline
\end{tabular}

Values along the same row with different superscript alphabets are significantly different $(P<0.05)$

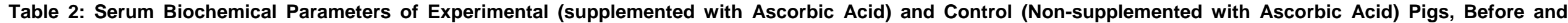
Immediately (30 min) After Long-Term (8 h) Road Transportation (Mean \pm SEM)

\begin{tabular}{|c|c|c|c|c|}
\hline \multirow[b]{2}{*}{ Parameters } & \multicolumn{2}{|c|}{ Before Transportation } & \multicolumn{2}{|c|}{ Immediately After Transportation } \\
\hline & Experimental $(n=17)$ & Control (n=12) & Experimental $(n=17)$ & Control $(n=12)$ \\
\hline Total Protein $(\mathrm{gm} / \mathrm{dl})$ & $70.29 \pm 1.19^{\mathrm{NS}}$ & $71.30 \pm 1.42^{\mathrm{NS}}$ & $69.41 \pm 1.11^{\mathrm{NS}}$ & $69.33 \pm 0.66^{\mathrm{NS}}$ \\
\hline Globulin (gm/dl) & $34.95 \pm 1.71^{\mathrm{NS}}$ & $36.10 \pm 2.25^{\mathrm{NS}}$ & $34.88 \pm 1.08^{\mathrm{NS}}$ & $34.92 \pm 1.09^{\mathrm{NS}}$ \\
\hline Albumin:Globulin & $1.10 \pm 0.09^{\mathrm{NS}}$ & $1.03 \pm 0.11^{\mathrm{NS}}$ & $1.00 \pm 0.05^{\mathrm{NS}}$ & $1.07 \pm 0.07^{\mathrm{NS}}$ \\
\hline $\mathrm{Na}^{+}(\mathrm{mmol} / \mathrm{L})$ & $139.20 \pm 0.69^{\mathrm{NS}}$ & $139.80 \pm 0.84^{\mathrm{NS}}$ & $140.18 \pm 0.82^{\mathrm{NS}}$ & $140.21 \pm 1.02^{\mathrm{NS}}$ \\
\hline $\mathrm{K}^{+}(\mathrm{mmol} / \mathrm{L})$ & $5.69 \pm 0.13^{\mathrm{NS}}$ & $6.04 \pm 0.17^{\mathrm{NS}}$ & $5.54 \pm 0.16^{\mathrm{NS}}$ & $4.92 \pm 0.16^{\mathrm{NS}}$ \\
\hline $\mathrm{HCO}_{3}^{-}(\mathrm{mmol} / \mathrm{L})$ & $25.53 \pm 0.64^{\mathrm{NS}}$ & $26.18 \pm 0.86^{\mathrm{NS}}$ & $26.65 \pm 0.72^{\mathrm{NS}}$ & $26.58 \pm 0.68^{\mathrm{NS}}$ \\
\hline Alkaline phosphatase (I.U./L) & $59.41 \pm 2.43^{\mathrm{NS}}$ & $65.18 \pm 1.57^{\mathrm{NS}}$ & $53.65 \pm 3.52^{\mathrm{NS}}$ & $50.83 \pm 4.02^{\mathrm{NS}}$ \\
\hline Aspartate amino transferase (I.U./L) & $14.41 \pm 0.98^{\mathrm{NS}}$ & $13.73 \pm 0.96^{\mathrm{NS}}$ & $15.94 \pm 1.96^{\mathrm{a}}$ & $13.33 \pm 0.98^{b}$ \\
\hline Alanine amino transferase(I.U./L) & $28.35 \pm 2.18^{\mathrm{NS}}$ & $31.08 \pm 1.79^{\mathrm{NS}}$ & $30.12 \pm 1.38^{a}$ & $25.27 \pm 1.88^{\mathrm{b}}$ \\
\hline Cholesterol (mg/100ml) & $4.89 \pm 0.15^{\mathrm{NS}}$ & $4.81 \pm 0.21^{\mathrm{NS}}$ & $4.55 \pm 0.12^{\mathrm{NS}}$ & $4.56 \pm 0.13^{\mathrm{NS}}$ \\
\hline Bilirubin $(\mathrm{mg} / 100 \mathrm{ml})$ & $8.59 \pm 0.66^{\mathrm{NS}}$ & $8.37 \pm 0.66^{\mathrm{NS}}$ & $9.65 \pm 0.56^{\mathrm{NS}}$ & $8.92 \pm 0.78^{\mathrm{NS}}$ \\
\hline Urea $(\mathrm{mg} / 100 \mathrm{ml})$ & $4.51 \pm 0.17^{\mathrm{NS}}$ & $4.71 \pm 0.24^{\mathrm{NS}}$ & $4.94 \pm 0.19^{a}$ & $7.56 \pm 2.60^{\mathrm{b}}$ \\
\hline
\end{tabular}


Agric. Biol. J. N. Am., 2011, 2(8): 1143-1150

Table 3 Serum Biochemical Parameters of Experimental (supplemented with Ascorbic Acid) and Control Non- supplemented with Ascorbic Acid) Pigs on Day 7 after Long-Term (8 h) Road Transportation (Mean \pm SEM)

\begin{tabular}{lll}
\hline \multicolumn{1}{c}{ Parameters } & Experimental $(\boldsymbol{n}=17)$ & Control $(n=12)$ \\
\hline Total Protein $(\mathrm{gm} / \mathrm{dl})$ & $70.65 \pm 1.12^{\mathrm{NS}}$ & $68.50 \pm 1.06^{\mathrm{NS}}$ \\
Globulin (gm/dl) & $35.71 \pm 0.87^{\mathrm{NS}}$ & $34.58 \pm 1.33^{\mathrm{NS}}$ \\
Albumin (gm/dl) & $34.94 \pm 0.84^{\mathrm{NS}}$ & $33.92 \pm 0.67^{\mathrm{NS}}$ \\
Albumin:Globulin & $0.98 \pm 0.03^{\mathrm{NS}}$ & $1.00 \pm 0.06^{\mathrm{NS}}$ \\
$\mathrm{Na}^{+}(\mathrm{mmol} / \mathrm{L})$ & $140.50 \pm 1.04^{\mathrm{NS}}$ & $139.20 \pm 0.63^{\mathrm{NS}}$ \\
$\mathrm{K}^{+}(\mathrm{mmol} / \mathrm{L})$ & $8.28 \pm 2.80^{\mathrm{NS}}$ & $5.49 \pm 0.16^{\mathrm{NS}}$ \\
$\mathrm{HCO}_{3}^{-}(\mathrm{mmol} / \mathrm{L})$ & $26.29 \pm 0.61^{\mathrm{NS}}$ & $24.58 \pm 0.73^{\mathrm{NS}}$ \\
$\mathrm{Cl}^{-}(\mathrm{mmol} / \mathrm{L})$ & $99.94 \pm 0.61^{\mathrm{NS}}$ & $99.17 \pm 0.70^{\mathrm{NS}}$ \\
Alkaline phosphatase (I.U./L) & $57.59 \pm 2.48^{\mathrm{NS}}$ & $57.50 \pm 3.39^{\mathrm{NS}}$ \\
Aspartate amino transferase (I.U./L) & $14.29 \pm 1.12^{\mathrm{NS}}$ & $16.75 \pm 1.34^{\mathrm{NS}}$ \\
Alanine amino transferase(I.U./L) & $31.67 \pm 1.27^{\mathrm{NS}}$ & $33.67 \pm 1.69^{\mathrm{NS}}$ \\
Cholesterol (mg/100ml) & $4.64 \pm 0.11^{\mathrm{NS}}$ & $8.76 \pm 4.02^{\mathrm{NS}}$ \\
Bilirubin (mg/100ml) & $9.58 \pm 0.58^{\mathrm{NS}}$ & $9.25 \pm 0.65^{\mathrm{NS}}$ \\
Urea (mg/100ml) & $5.45 \pm 0.19^{\mathrm{NS}}$ & $5.67 \pm 0.20^{\mathrm{NS}}$ \\
\hline
\end{tabular}

Values along the same row with different superscript alphabets are significantly different $(P<0.05)$

\section{DISCUSSION}

Haematological parameters and clinical chemistry of pigs transported by road for eight hours

The observed PCV value obtained in the present study agree with the findings of Plyaschenko and Sidorov (1987), Adenkola et al. (2009c) and Scope et al. (2002), who observed increase but no significant changes in the PCV values of pigs and racing pigeons after 4 -h of road transportation respectively. The fact that leucocytosis was observed in the control pigs and not in AA administered pigs immediately after transportation suggests that AA might have prevented the release of leucocytes from body pool into the peripheral circulation, apparently due to inhibitory role of $A A$ on circulating corticosteroids in pigs under stress. This finding is similar to that of Kannan et al. (2000), but disagrees with the result obtained by Gallipalli et al. (2004), who observed that there was no significant change in the leucocyte profiles of Boer goats administered with tascoweed (Ascophyllum nodosum) and transported by road. It is possible that tascoweed (Ascophyllum nodosum) given to the goats as an antioxidant is not as potent as AA administered to pigs in this study. The leucocyte profiles suggest that transportation stress may have a prolonged effect in pigs and that it may suppress their immunocompetence. A further study is required to elucidate the effect of leucocyte on immune response of transported pigs.

Road transportation of pigs did not alter eosinophil count significantly in experimental and control pigs, but a significant rise occurred in the value of eosinophils in the control pigs post-transportation over the value obtained pre-transportation. This may be attributed to the physical and emotional stress that the pigs were subjected to during the journey, resulting, apparently, in elevated levels of plasma adrenaline and cortisol concentration. This is in agreement with the findings of New et al. (1996) and those of Gallipalli et al. (2004), who did not observe any significant increase in eosinophils after supplementing transported Boer goats with tascoweed (Ascophyllum nodosum) which contains an antioxidant. Supplementation with antioxidant suppresses an increase in eosinophils in the present study. The fact that monocytosis was observed following road transportation in control pigs, and not in experimental pigs, disagreed with the result of Scope et al. (2002) who did not observe any significant changes in monocyte count in transported racing pigeon for 4-h by road. Neutrophilia observed in the present study may be due to the antioxidant effect of the AA which may inhibit the mobilization of neutrophils from the body pools into the peripheral circulation. The mechanism involved was not elucidated in this study. However, this is similar to the findings of Gallipalli et al. (2004) that tascoweed (Ascophyllum nodosum) increased antioxidant activity and immune responses following road transportation in goats. Lymphopenia observed in the experimental pigs may be attributed to the 
suppressive effects of road transportation on lymphoid tissues. This is in agreement with the finding of Sudakov (1992), who showed that ACTH and glucocorticoid cause regression of lymphoid tissue under stressful conditions. The result of the present study supported the findings of Kannan et al. (2000), Scope et al. (2002) and that of Gallipalli et al. (2004) in boer goats that lymphocyte count decreases significantly in animals due to road transportation stress. The increase in neutrophils:lymphocyte ratio after transportation obtained in the present study is similar to the findings of Kannan et al. (2000) and Rajion et al. (2001), who observed similar increase in the ratio following road transportation in goats. Similar results were also observed by Schaefer et al. (1997) and Kegley et al. (1997) in cattle. The results of the present study are in agreement with the findings that the parameter is a good indicator of stress in goats (Rajion et al., 2001; Minka and Ayo, 2007), calves (Fraser and Brown, 1990) and broiler chickens (Zulkifli et al., 2001). An increase in neutrophil:lymphocyte ratio and a decrease in lymphocyte count are consistent with the finding that stress-induced neutrophilia stimulates the anterior pituitary gland to secrete ACTH. Circulating ACTH in turn induces the adrenal cortex to produce glucocorticoids, involved in the mobilization of neutrophils from body pools into the pheripheral circulation. The increase in the neutrophil:lymphocyte ratio, lymphopenia and neutrophilia may serve as good indicators of transportation stress in pigs.

The non-significant increase in TP post-transportation in all the groups disagrees with the observation of Knowles et al. (1996) and Rajesh et al. (2003), in sheep and in calves by Knowles et al. (1999). The difference in the results may be due to the species of the animals and duration of the journey. Sodium, potassium and chloride are involved in various fundamental physiological processes, including the maintenance of normal osmotic equilibrium; normal water balance and distribution; maintenance of normal acid-base equilibrium; and maintenance of neuromuscular function (Coles, 1986). Nonsignificance in the values of these parameters posttransportation in experimental and pigs indicated that AA administration in pigs before 8-h road transportation did not affect these important physiological processes. The significant decrease in transaminase enzyme observed in control pigs immediately after transportation may be due to enormous free radicals produced which, apparently, inhibit secretions of the enzyme by the hepatocyte.
However, an increase in the values of these enzymes 7 days post-transportation indicated severe damages to the muscle and the liver, especially in the control pigs, which increase the elevation of this enzyme. The result is similar to that obtained by Stull and Rodiek $(2000 ; 2002)$ that horses transported for 24-h during summer showed an increase in transaminase enzyme. The maintenance of the transaminase enzyme value in the experimental pigs is an indication of the protective effect of $A A$ in scavenging free radicals and ameliorating the stressful condition. The increased level of urea observed after the transportation is similar to the finding of Kannan et al. (2000), which and this may be due to feed deprivation and elevated cortisol concentration (which was not done in this study) as reported by several authors (Dalin et al., 1993; Kannan et al., 2000; Stull and Rodiek, 2000; Odore et al., 2004). AA supplementation has been found to limit the rise in circulating corticosterone concentration under stress (Pardue et al., 1985).

\section{CONCLUSION}

The results of the present study demonstrated for the first time the beneficial effect of AA administration on haematology and serum chemistry of pigs transported by road during the harmattan season for long journey of 8-h. It is, therefore, recommended that pigs be administered with AA before transportation by road during the harmattan season in order to reduce the risk of adverse effects of transportation stress on health.

\section{REFERENCES}

Adenkola, A. Y. and Durotoye L. A (2004). Haematological study during prepartum and postpartum periods in brown savanna does in Zaria, Nigeria. Proc. $38^{\text {th }}$ Ann. Conf. Agric. Soc. Nig. 38: $538-540$

Adenkola, A. Y. and Ayo J. O (2009a). Effect of road transportation on erythrocyte osmotic fragility of pigs administered ascorbic acid during the harmattan season in Zaria Nigeria. J. Cell Anim. Biol. 3(1): 4-8.

Adenkola, A. Y. and Ayo J. O (2009b). Physiological and behavioural responses of livvstock to road transportation stress: A Review. Afric. J. Biotech. (Accepted in press)

Adenkola, A.Y., Ayo, J. O., Sackey, A. K. B., Adelaiye, A. B. and Minka, N. S (2009a). Excitability scores of pigs administered ascorbic acid and transported during the harmattan season. Veterinarski Arhiv, 79 (5), 471-480.

Adenkola, A.Y., Ayo, J. O., Sackey, A. K. B. and Adelaiye, A. B (2009b). Modulatory role of ascorbic acid on rectal temperature of pigs transported by road during the harmattan season. Anim. Produc. Res. Adv. 5(2): $120-127$. 
Adenkola, A. Y., Ayo, J. O., Sackey, A.K.B and Adelaiye, A. B (2009c). Haematological changes in pigs administered with ascorbic acid and transported by road for four hours during the harmattan season. J. Cell Anim. Biol. 3 (2): 021- 028.

Ayo J. O. and Oladele, S. B (1996). Road transport stress in food animals in Nigeria: A review. Nig. Vet. J. (Special Edition). 1(1): 49-57.

Bradshaw, R. H., Hall S. J. and Broom, D. M (1996a). Behaviour and cortisol responses of pigs and sheep during transport. Vet. Rec. 138: 253 - 254.

Bradshaw, R. H., Parrot R. F., Goode J. A., Lloyd D. M., Rodway R. G. and Broom, D. M. (1996b). Behaviour and hormonal responses of pigs during transport: effect of mixing and duration of journey. Anim.Sci. 62 : 547- 5554

Buckham Sporer K. R., Weber P. S., Burton J. L., Earley B. and Crowe M. A (2008). Transportation of young beef bulls alters circulating physiological parameters that may be effective biomakers of stress. J. Anim. Sci. 86: $1325-1334$.

Cheesbrough, M (1991). Medical Laboratory Manual for Tropical Countries. ELBS. Ed. pp. 465-545.

Chervyakov, D. K, Yevdokimov P. D. and Vishker, A. S (1970). Drugs in Veterinary Medicine. Kolos Publishing House, Moscow, 496pp (in Russian).

Coles, E. H (1986). Veterinary Clinical Pathology, $4^{\text {th }}$ Ed. W. B. Saunders Company, Philadelphia, 455 pp.

Dalin, A. M., Magnusson H. J., Nyberg, L (1993). The effect of transport stress on plasma catecholamines, cortisol, corticosteroids-binding globulin, blood cell count and lymphocyte proliferation in pigs. Acta Vet. Scand. 34: 59-68.

Frazer, A. F. and Brown, D. M (1990). Farm Animal Behaviour and Welfare. $3^{\text {rd }} \mathrm{Ed}$. CAB International, Wallingford, U.K.

Galipalli, S., Gadiyaram, K. M., Kouakou, B., Terrill, T. H. and Kannan, G (2004). Physiological resonses to preslaughter transportation stress in Tascosupplemented Boer goats. South Afric. J. Anim. Sci. 34(1): 198- 200

Grandin, T (1993). Introduction: management and economic factors of handling and transport, In: Livestock Handling and Transport. Ed. T.Grandin, Wallingford, CAB International, pp 1-9.

Gupta, S., Earley, B. and Crowe, M. A (2007). Effect of 12$h$ road transportation on physiological, immunological and haematological parameters in bulls housed at different space allowances, Vet. J. 173: 605 -616.

Igono, M. O. and Aliu, Y. O (1982). Environmental profile and milk production in Friesian-Zebu crosses in Nigeria Guinea Savanna. Int. J. Biometeorol. 26: 115 - 120.
Kannan, G., Terrill T. H., Konakou, B., Gazal, O. S., Gelaye, S., Amoah, E. A. and Samake, S. (2000). Transportation of goats: Effects on physiological stress responses and live weights loss. J. Anim. Sci., 78: $1450-1457$.

Kafri, I. and Cherry, J. A. (1984): Supplemental ascorbic acid and heat stress in broiler chicks. Poultry Science, 63(suppl.): 125.

Kay, R., Hall, C (2009). The use of a mirror reduces isolation stress in horses being transported by trailer. Appl. Anim. Behav. Sci. 116: 237- 243.

Kegley, E. B., Spears J. W. and Brown Jr, T. T (1997). Effect of shipping and chromium supplementation on performance, immune response, and disease resistance of steers. J. Anim. Sci. 75: 1956 - 1964.

Knowles, T. G., Ball R. C., Warris P. D. and Brown S. N (1996). A survey to investigate potential dehydration in slaughtered broiler chickens. Brit. Vet. J. 152: 307-314.

Knowles, T. G, Brown S. N., Edwards J. E. and Warris, P. D. (1999): Effect on cattle of transportation by road for up to 31-hours. Vet. Rec. 145: 575- 582.

Lambooij, E. (2000). Transport of pigs. In Livestock Handling and Transport. (Ed. T. Grandin.) CABI Publishing,, New York. pp 275 - 296.

Minka, N. S. and Ayo, J. O (2007). Physiological responses of transported goats treated with ascorbic acid during the hot-dry season. Anim. Sci. J. 78: 164 -172.

Mstl, E., Palme, R (2006). Hormones as indicator of stress. Dom. Anim.Endocrinol. 23: 67 - 74.

New, T. M., Itori, E., Manda, M. and Watanabe, S (1996). Significance of catecholamines and cortisol levels in blood during transportation stress in goats. Small Ruminant Res. 20: 129 - 135.

Odore R., Angelo A. D., Badino P., Bellino C., Pagliasso S., Re G. (2004): Road transportation affects blood hormone levels and lymphocyte glucocorticoid and ßadrenergic receptors concentration in calves. Vet. J. 168: 297 - 303.

Oyewale, J. O (1992). Changes in osmotic resistance of erythrocytes of cattle, pigs rats, and rabbits during variations in temperature and $\mathrm{pH}$. J. Vet. Med. A39: 98 - 104.

Pardue, S. L., Thaxton J. P. and Brake, J. (1985). Role of ascorbic acid in chicks exposed to high environmental temperature. J. Appl. Physiol. 58: 1511 - 1516.

Plyaschenko, S. I. and Sidorov, V. T. (1987). Stress in farm animals. Agropromizdat, Moscow, 192pp (In Russian).

Rajesh, B., Maralidharan M. R., Ramesh V., Arunachalam S. and Sivakumar, T. (2003): Effects of transport stress on blood profile in sheep. Ind. Vet. J. 80: $511-514$. 
Rajion, M. A., Mohammed, S., Zukifti, L., Goh, Y. M (2001). The effect of road transportation on some physiological stress measures in goats. Asian-Austral. J. Anim. Sci. 9: $1250-1262$.

Sen, C. K (2001). Antioxidant in exercise. Nutri. Sports Med. 31: $891-908$.

Schaefer, A. L., Jones, S. D. M. and Stanley, R. W (1997). The use of electrolyte solutions for reducing transport stress. J. Anim. Sci.75: 258- 265.

Schales, O. and Schales, S. S. (1941). A simple and accurate method for the determination of chloride in biological fluids. J. Biolo. Chem. 140: 979 - 984.

Schalm, O. W., Jain, N. C. and Caroll E. J (1975): Textbook of Veterinary Haematology $2^{\text {nd }}$ Edn. Published by Lea and Febiger Philadelphia, pp. $129-250$.

Scope, A., Filip, T., Gabler, C. and Resch, F. (2002). The influence of stress from transport and handling on haematologic and clinical chemistry. Blood parameters of racing pigeons. (Columba livia domestica). Avian Dis. $46,224-229$.

Sudakov, K. V. (1992). Stress postulate: analysis from the position of general theory of functional systems. Pathophysiol. Experim. Therap., 4: 86-93.

Stull, C. L., Rodiek A. V (2000). Physiological responses of horses to 24 hours of transportation using a commercial van during summer conditions. J. Anim. Sci.78: 1458 - 1466.

Stull, C. L. and Rodiek, A. V (2002). Effects of cross-tying horses during $24 \mathrm{~h}$ of road transport. Equine Vet. J. 34(6): 550- 555.

Warriss P. D. (1998): Choosing appropriate space allowance for slaughter pigs transported by road: a review. Veterinary Record, 142, 449- 454.

Zulkifli, I, Norma, M. T., Chong, C. H., Loh, T. C (2001). The effects of crating and road transportation on stress and fear responses of broiler chickens treated with ascorbic acid. Archiv. Geflugelk, 65(1), 33-37. 